\title{
The Review on the 40 Years of Marketization Reform in China's Power Industry and Its Future Prospects
}

\author{
Kun Xiao \\ Research Center for Environment and Health \\ Zhongnan University of Economics and Law \\ Wuhan, China 430000 \\ School of Business Administration \\ Zhongnan University of Economics and Law \\ Wuhan, China 430000
}

\author{
Yi Wang \\ State Grid Xianning Electric Power Supply Corporation \\ Xianning, China 437000
}

\author{
Jingdong Zhang* \\ Research Center for Environment and Health \\ Zhongnan University of Economics and Law \\ Wuhan, China 430000 \\ School of Business Administration \\ Zhongnan University of Economics and Law \\ Wuhan, China 430000 \\ *Corresponding Author
}

\begin{abstract}
In the past 40 years, China's power industry reform has made remarkable achievements, and it has explored a development path that is in line with national conditions. This paper sorts out its reform, summarizes the research results and prospects the future development. The study found that its reform has experienced three stages: startup, speed-up and exploration, that is, from backward capacity transformation to "plant and network separation" to electricity market trading. In recent years, the green card transaction and carbon trading have pushed their reforms into the critical period and linked to the global reduction of carbon emissions. The challenges of the power industry in the future will focus on transmission and distribution prices and crosssubsidy approval, power transaction type co-ordination, interregional imbalances and inter-provincial barriers.
\end{abstract}

Keywords-power industry; reform and opening up; review

\section{INTRODUCTION}

In the 1990s, former Premier Li Peng pointed out: "If the economy is to develop, electricity must go first." As a basic industry for the development of the national economy, electric power has provided a strong and dynamic force for China's reform and opening up in the past 40 years: China's power generation has jumped to the top in the world in 2011, and has continued to expand the gap with the second (US), becoming the energy pillar of China's economic construction; China has invested in the production of the world's only UHV grid for commercial transportation, and it is second to none in terms of energy efficiency and clean deployment capability over long distances and large scales. At the same time, in order to better adapt to and meet the needs of China's economic development in different periods, China has initiated two rounds of large-scale power market reform based on the advanced experience of other countries, constantly adjusting, optimizing the industrial structure and improving the quality of energy supply.

The reform of power marketization is an important part of China's reform and opening up in various industries in the past 40 years. It is also constantly exploring the progress of the marketization and planning system. Xi Jinping pointed out that at present, China's reform has entered the critical period. Past experience, if not forgotten, may serve as a guide for the future. It's of great importance and significance for the reform and development of China's power industry in the future to summarize the existing lesson

\section{A REVIEW OF THE MARKETIZATION REFORM OF THE POWER INDUSTRY}

From a macro perspective, China's drastic reform and opening up has distinct characteristics of the times. The economic development situation, tasks and needs are varied in different periods, which directly affect the dynamic changes in the contradiction between power supply and demand. In general, the reforms in different periods can be divided into the following three stages:

\section{A. The Early Period of Reform and Opening up (1978-2000)}

At this stage, all walks of life in China began to develop at a high speed. The demand for energy consumption in the whole society increased sharply, while the power production and distribution capacity was short, and the technology was 
backward, which could not meet the needs of economic development. At the same time, the demand highlighted by the power industry is capital and technology. Therefore, since the 1980s, China has adopted the method of introducing foreign capital or local fund-raising, vigorously developing thermal power generation construction, and focusing on investing in the construction of several largescale hydropower stations, initially completing the upgrading of urban distribution networks to meet the rapid growth of economic development and power demand. In order to guarantee the order of social energy, China's electric power has adopted a strong plan management system at this stage.

\section{B. The Period of Accelerated Reform and Opening up (2001-2013)}

After 20 years of construction and accumulation in the previous stage, China has initially completed the transition of the planned economy to the socialist market economy and successfully joined the WTO. The development vitality of various industries has been fully released. At this stage, although China's industrial growth momentum continues to drive the growth of electricity consumption, and the demand for electricity consumption in the service industry and residents' lives is growing, but the nationwide power shortage has been reversed based on the large-scale power generation infrastructure in the previous stage. In 1997, China established the State GRID Corporation of China; in March 1998, the Ministry of Electric Power was abolished, marking the historic turning point of China's power industry's transition from a planned economy to a socialist market economy. In 2000, the State GRID Corporation of China was first entered the world's top 500. However, the strict power plan allocation method restricts the ability of other industry enterprises to adjust production according to market demand. At the same time, the "integration between factory and network" management model makes it difficult for the State GRID Corporation of China to keep up with the pace of the market economy in management and operation. The problem of inefficiency is outstanding, and the voice of power market operation is soaring.

In this context, China launched the first round of power market reform with the "Notice of the State Council on the Reform of the Power System" as mark (GuoFa [2002] No. 5). Although this round of reforms has been given many expectations, all walks of life hope to build a large and comprehensive power market with Chinese characteristics, but in reality, they have only completed the reform task of "separation of plant and network". Others goals such as "implementing power generation bidding online", "establishing a competitive and open regional electricity market" and "changing the pattern of exclusive purchase of electricity by power grid enterprises" have not been realized. Most of these unrealized reform targets have been piloted in some regions during the current round of power cycle. The reason is mainly due to the macroscopic supply and demand situation of power and technical conditions: although the shortage of power supply at this stage has been reversed, it still appears to be demand-side growth to drive supply, and the local and short-term power supply gap has not been completely eliminated; The inter-regional power interaction capability is weak, the power grid is not strong enough, and the safety and stability scheduling margin is insufficient.

\section{Reform and Opening up Entered the Critical Period (2013-Present)}

At this stage, affected by the international and domestic macroeconomics, the growth rate of various industries in China has slowed down from the previous stage. The transformation of industrial structure and economic development has become the main task of China's economic reform and development at this stage. At the same time, there is a shortage of resources. Problems such as environmental degradation and regional imbalances have increasingly become a stumbling block to China's economic development. The 18th National Congress of the Communist Party of China first proposed the strategy of "supply-side reform", and a new round of electricity reform was ready.

In terms of China's power supply and demand situation and technical conditions in this period, it's obvious that on the one hand, the power supply tension situation has been greatly alleviated due to the slowdown in the growth of power demand in various industries, while the new energy installed capacity is growing rapidly, and some areas even have excess power generation installed capacity; On the other hand, the power grid in northern, eastern and central China is simultaneously connected to the network, the "three vertical and three horizontal" UHV construction is put into operation, and the Xinjiang power transmission channel is completed. The provincial power grids basically realize the construction of the main network of "500kV as the skeleton and $220 \mathrm{kV}$ as the brace". The strength of the power grid has been greatly improved compared with the previous stage, and the safety and stability scheduling margin is sufficient. These have provided strong support for further development of the power market reform.

At this stage, the main contradiction between power supply and demand and the industry is as follows: first, the social industry, especially the industry, has higher expectations for "cost reduction", and reducing the cost of using energy (electricity) in industrial production is an important part; second, the contradiction between the failure to use clean energy at its best and environmental and resource problems such as frequent smog and resource depletion is intensified. Wasted wind, wasted light and wasted water are huge in the north and southwest regions, and the pressure to deploy coal and control sewage has increased sharply due to coal-fired power; third, the grid price of power in different regions and different types is unbalanced, and there are barriers to power trading between regions, which restrict the development of clean energy and efficient configuration. In addition, the parties have different expectations on the direction and extent of these contradictions, and the differences in interest demands are also a major difficulty in the reform of the power industry at this stage.

The 2015 "Several Opinions on Further Deepening the Reform of the Power System" (ZhongFa [2015] No. 9 
Document) and the issuance of its six supporting documents marked the start of the reform of the power marketization transaction in the whole process from generation, transmission, distribution to sale. The idea is to "open up the two ends and supervise the middle", that is, to fully introduce competition on the power generation side and the power sales side, use market means to improve energy utilization efficiency, and strictly supervise the transmission link, verify the transmission and distribution costs, clarify the cross subsidies, and restore the original commodity attribute of electrical energy. The focus is to guide the power generation in the process of low-cost coal consumption or clean energy, and to exclude enterprises with poor production capacity and serious pollution from the list of trading licenses, and to introduce competition in price and time, so that the demand for cross-provincial power needs and cross-regional responses are possible.

On February 3, 2017, the National Development and Reform Commission, Ministry of Finance of the People's Republic of China, and National Energy Administration issued the Notice on the Trial Implementation of the Green Power Certificate for Renewable Energy and the Voluntary Subscription System. On December 19, 2017, the National Development and Reform Commission officially issued "National Carbon Emissions Trading Market Construction Plan (Power Generation Industry)" with the approval of the State Council. These two policies have provided new breakthroughs for China's electricity reform.

As of January 2017, China has established two nationallevel power trading centers in Beijing and Guangzhou, and has established branches in various regions, also established relatively independent provincial-level power trading centers in each province which has introduced electricity trading rules with distinctive features. Different types of power trading have been fully implemented in China with trading methods and trading models continue to innovate. In addition to various types of transactions in the provincial power market, some regions have begun to try to "cross-regional power direct transactions", "Trans-regional power generation trading for rights", "waste of water and electricity spot transactions", etc. at this stage. The proportion of marketbased transaction power to total power consumption is getting higher and higher, and the cost of electricity consumption is reduced to varying degrees in different regions.

From the perspective of the 40 -year reform process, the contradictions and tasks faced by China's power industry in different periods are dynamically changing. Its reform has experienced three stages of starting, speeding up and exploring, from backward capacity transformation to "separation of factory and network" to electricity market trading. This determines that reform is not a "one-for-all" deal, but requires sustained and determined determination to constantly adjust the operational management model to meet the needs of economic and social development.

\section{SUMMARY OF RESEARCH RESULTS ON MARKET- ORIENTED REFORM OF THE POWER INDUSTRY}

China's power industry reform is an important part of China's 40 years of reform and opening up. How to reform, adjust and develop the power industry to match China's reform and opening up have always been the focus of scholars and the research focus on different key points at different stages. It is said that these studies are centered on two aspects: "How should China's power industry change?" and "How should China's power market be built?"

In the early stage of reform and opening up, how to reform China's electric power to better improve the utilization rate of funds and management efficiency is the main task. At that time, the study almost agreed that the pattern of "integrated political and enterprise" should be broken and the market-oriented operation system should be improved [1], [2]. At the time when the thought and management system had not been completely liberated, Dazhen Shi, then Minister of the Ministry of Power Industry, took the lead in conceiving the mode of operation of electric power in the form of enterprises ${ }^{[2]}$; looking at the international world at that time, the United States, Britain, Australia, New Zealand and other countries took the lead in power generation system reform and have provided some successful experiences for China's power generation system reform to introduce competition mechanism, and improve efficiency [3], [4], [5], [6], [7], [8]. Before the reform, the US power industry was private, and the Commonwealth country's power industry was basically state-owned. Thus, the reform experience of Commonwealth countries is more useful.

With the advancement of reforms, the question of how the electricity market should operate, how the ownership form and management model should be set, and how relevant supporting laws should be formulated is discussed [9], [10]. The results of foreign power reform have also provided useful experience for these early studies ${ }^{[11-16]}$, and proposed suggestions for China's power market reform in the next stage from the perspectives of legislation, supervision, price mechanism, and management methods.

Standing in the perspective of 2019 , the above-mentioned research was optimistic about the "market omnipotence" and believed that the power marketization policy could solve the problems faced by China's power industry once and for all. However, the California power crisis of 2000 "cooled down" these optimisms [17]. The drawbacks in electrical reform exposed in the California Power Crisis were taken seriously, and everyone realized that the government's control over electricity prices, construction planning, and orderly dispatching is indispensable [17], [18], [19]. According to comparative studies by scholars, the British-style "plant-net separation" mode of operation is more in line with China's national conditions [20], [21].

After China's first round of electricity reform in 2002 realized the "separation of plant and network", how to build China's power market has become a research hotspot. Based on the experience of foreign countries, some scholars first study how to introduce the types of transactions such as 
direct electricity trading and inter-regional power exchange transactions into China and realize further growth [22], [23]. Although limited by actual conditions, these early ideas were not immediately implemented. Scholars have studied the power generation bidding, transmission and distribution price, and trading methods for more than ten years [24] [25] [26] [27] [28] [29] to lay a solid theoretical foundation for the second round of electricity reform. In addition, combined with China's unique national conditions, some scholars have innovated and proposed the power generation for right, a unique power trading model in China [30], [31], [32], [33]. These studies provide theoretical support for the future pilots of various types of power trading.

After the first two stages of development in theory, technology and power industry construction, and the marketoriented power transactions were launched nationwide as soon as the second round of power reform was on. Scholars have begun to pay attention to the details of the problems exposed in the transaction, such as price formation mechanism [34], [35], [36], deviation control method [37], [38], [39], [40], auxiliary service [41], [42], [43] and transaction method [44], [45], [46]. At the same time, the development of inter-regional power transactions varies widely, and some studies focus on how to build a platform that meets the needs of differentiated power trading in various regions of China [47] [48]. In recent years, issues such as environmental protection and clean energy utilization have become popular, and quite a number of scholars have studied and called for the introduction of "green card transactions" [49], [50] and carbon trading [51], [52] in power trading.

These research results have comprehensively covered the macroscopic concept and micro-links of China's power reform, and promoted the continuous revision, breakthrough and innovation of the reform and development of the power industry. Early research focused on changing to solve the backward development of China's power industry. In recent years, research has focused on optimizing industrial structure and supply quality. At the same time, these studies have a distinctive Chinese DNA and provide "Chinese wisdom" for the reform and development of the power industry in other countries of the world.

\section{The Future CHALlENGES OF THE MARKETIZATION REFORM OF THE POWER INDUSTRY}

It has been five years since the second round of power reform began, the national electricity trading market has been completed, and the global reduction of carbon emissions has become the focus of industrial restructuring. The 19th National Congress proposed the development strategy of "building beautiful China", and the green certificate trading and carbon trading have pushed electric power reform to a critical period, which has brought many new challenges to the current power industry reform. It is necessary to carry out theoretical research and practice pilots in the future, which mainly include the following aspects:

\section{A. It is Difficult to Verify Transmission and Distribution Price and Cross-subsidization Prices}

The verification of transmission and distribution price and cross-subsidization prices is directly related to the rationality assessment of the "electricity-carbon" market price mechanism. Since the cost of transmission and distribution price is directly affected by the operation mode of the power grid, while it is inevitable that the operation mode of the power grid will be constantly adjusted in the dispatching, which makes the uncertainty of the power flow change of the power grid large, and it is difficult to accurately measure the transmission and distribution cost. In addition, the long-standing cross-subsidization prices in China is complicated, and the transmission and distribution cost is not accurate, so it is impossible to further calculate the subsidy share. This has created obstacles to the realization of the goal of "approving transmission and distribution costs and clarifying cross-subsidization prices" proposed by the second round of power reform. Measuring transmission and distribution costs requires the integration of statistical, economics and electrical engineering knowledge, and makes breakthroughs in theory and algorithms.

\section{B. Different Types of Power Transactions Need to be Further Coordinated and Organized}

Some types of power transactions have a high degree of similarity in mechanism (such as power generation trading and carbon trading), or some transactions have execution conflicts in the organization, which makes the trading entity easy to be troubled by the choice of trading methods, or the implementation bias in production is large. All these require further study on how the transaction organization is coordinated in the future.

\section{The Problem of Inter-regional Imbalances and Inter- provincial Barriers Needs Further Research and Resolution}

Inter-regional imbalances are largely due to resource endowments, price approvals, and planning imbalances, while inter-provincial barriers are more likely to come from local protectionism. This hinders the more economical and quality deployment of energy, including electricity. Designing a reasonable form of power trading organization, setting up a smooth demand response platform, formulating an effective power market supervision system, and constructing a win-win interest distribution mechanism are all indispensable. These are subject to follow-up research and are constantly being explored.

The emergence of these challenges is the inevitable result of China's reform entering the critical period, and it is difficult to directly find relevant experience and lessons from abroad. However, as President Xi Jinping pointed out at the private enterprise symposium on the 40th anniversary of reform and opening up, "Difficulties are difficulties in development, problems in progress, and troubles in growth, and they can certainly be solved in development." 


\section{CONCLUSION}

This paper summarizes the road to reform and development of the power industry in the past 40 years of reform and opening up. It summarizes the reform of China's power industry and the research results, and forecasts the future reform of China's power industry. Practice shows that China's power industry reform should adapt to the needs of economic development and its own industry foundation; It should focuses on the actual situation of the country, make sufficient theoretical research, and continuously improve the exposed problems on the basis of learning from foreign experience. It's a must to continue to promote power reform, making it a strong pillar of the reform and opening up of all industries in China.

\section{REFERENCES}

[1] World Bank Experts Talk About China's Power Reform [J]. East China Electric Power, 1993(09):17. (in Chinese)

[2] Dazhen Shi. Standardized Shareholding System: the Only Way for Power Reform and Development [J]. Economy\&Science, 1994(03):2. (in Chinese)

[3] Zunlian Zhao, Chang Zhang. The Reform and Commercial Operation of the British Power Industry System [J]. Central China Electric Power, 1996(05):66-69. (in Chinese)

[4] Recent Developments in Electric Power Reform in Australia [J]. Yunnan Electric Power, 1996(08):60. (in Chinese)

[5] Chengzhang Zhu. A Unique Power Reform [J]. Rural Power Management, 1996(02):41-42. (in Chinese)

[6] Tingiie Guo. The Initial Results of Japan's Electric Power Reform [J]. Energy of China, 1997 (06): 45-47. (in Chinese)

[7] Jiexian Xu, Fuxing Wang. British Power Reform and Electricity Market [J]. China Power Enterprise Management, 1998 (09): 44-46.

[8] Chengzhang Zhu. Characteristics and Trends of World Power Reform [J]. Energy of China, 1999(12):26-28. (in Chinese)

[9] Ning Jie. Discussion on the Mode of Power Reform in Various Countries in the World (I) [J]. China Power Enterprise Management, 1998 (11): 52-54. (in Chinese)

[10] Ning Jie. Discussion on the Mode of Power Reform in Various Countries in the World (II) [J]. China Power Enterprise Management, 1998 (12): 53-55. (in Chinese)

[11] Rongzhen Ye. Improvement of the Italian Electricity Reform Act [J]. China Power Enterprise Management, 1999 (12): 25-26. (in Chinese)

[12] Lianzhong Xing. British Power Reform and Development and Power Market Operation [J]. East China Electric Power, 1999(05):57-60. (in Chinese)

[13] Jicheng Qiu. Comparison of the "Three Kingdoms" Model Introducing Competition Mechanism in Power Industry (I) $[\mathrm{J}]$. China Power Enterprise Management, 1999 (03): 48-50. (in Chinese)

[14] Bo Wen. On Government Regulation and Power Reform [J]. Electric Power Technologic Economics, 2000 (06): 11-14. (in Chinese)

[15] Rongzhen Ye, Tiecheng Tong. Korea Electric Power Reform and Electric Power Legislation [J]. China Power Enterprise Management, 2000 (02): 55-56. (in Chinese)

[16] Tingiie Guo . Learning From International Experience to Ensure the Smooth Progress of Power Reform [J]. Energy of China, 2000 (05): 39-42. (in Chinese)

[17] Zhou Liang. Thoughts on California Power Crisis [J]. Guangdong Electric Power, 2001 (06): 15-18. (in Chinese)

[18] Yanchun Yu, Keting Shen. Relaxing Government Control from the California Power Crisis [J]. Journal of Graduate School of the Chinese Academy of Social Sciences,2002(S1):51-54. (in Chinese)
[19] William L. Marseille. Marketization and Regulation: American Power Reform After the California Crisis [J]. China Power Enterprise Management, 2002 (03): 22-24.

[20] Wei He. Thoughts on Several Issues of Electric Power Reform [J]. Electric PowerTechnologic Economics, 2001(06):5-9. (in Chinese)

[21] Hougen Wang. The Reform of the Regulation of the British Power Industry and its Enlightenment [J]. China National Conditions and Strength, 2001 (Z1): 61-62. (in Chinese)

[22] Chao Wang. Research on Direct Power Purchase of Large Power Users Based on Game Theory [D]. Chongqing University, 2003. (in Chinese)

[23] Fen Wei. Discussion on Regional Electricity Market Model [J] Electric PowerTechnologic Economics, 2002(05):10-13. (in Chinese)

[24] Binghong Chen. Research on Direct Power Supply Mode for Large Users [D]. Tianjin University, 2009. (in Chinese)

[25] Linwei Xia. A Method for Calculating the Direct Transaction Capacity of Power Users Considering Load Characteristics [J]. East China Electric Power,2009,37(12):1975-1978. (in Chinese)

[26] Lang Shen. Analysis and Suggestions on Several Issues of Direct Power Trading Pilot $[\mathrm{J}]$. Electric Power Technologic Economics, 2011,23(12):34-38. (in Chinese)

[27] Jincheng Shang, Xian Zhang, Chuncheng Gao, Lin Guo, Yin Fang. Design and Implementation of Direct Trading Platform for Power Users and Power Generation Enterprises [J]. Power System Technology, 2011,35(09):199-204. (in Chinese)

[28] Tao Peng. Research on Regional Electricity Market Theory and Trading System [D]. Tsinghua University, 2005. (in Chinese)

[29] Jianhua Yang, Daqiang Xiao, Xuejun Tang, Wei Zhang. Design and Implementation of Energy Trading System for Regional Power Market in Central China Power Grid [J] .Power System Technology, 2008(20):90-94. (in Chinese)

[30] Canbing Li, Chongqing Kang, Qing Xia, Yongzhen Huang, Jincheng Shang, Yuanjing Meng, Junwei Ding, Yu Shen. The Power Generation Transaction and Its Mechanism Analysis [J]. Automation of Electrical Power Systems, 2003(06):13-18. (in Chinese)

[31] Wuyang Zhang. Study on the Game Behavior in the Transfer of Power Generation Rights [J]. Central China Electric Power, 2005(06):1-4. (in Chinese)

[32] Jiangang Yao, Qiliang Zhou, Jiaqi Zhang, Pan Huang. Model of Generation Rights Trading Based on Option Theory [J]. Proceedings of the CSEE, 2005(21): 79-84. (in Chinese)

[33] Jincheng Shang. Theory and Application of Power Generation Trading Based on Energy Saving and Emission Reduction (I) Theory of Power Generation Trading [J]. Automation of Electrical Power Systems, 2009, 33(12): 46 52. (in Chinese)

[34] Fengyun Wang, Yuqin Su, Xiaohu Li. Research on the Difficultie and Countermeasures of Verifying Transmission and Distribution Price under the Reform of Electric Power System [J]. Price: Theory and Practice, 2016(11): 62-65. (in Chinese)

[35] Song Xue, Xiaoyu Zhang. Control of Price Fluctuation Risk in Power Market [J]. China Power Enterprise Management, 2017(34):45-47. (in Chinese)

[36] Lizi Zhang. Discussion on the Market Reform Path of China's Electricity Price Mechanism [J]. Price: Theory and Practice, 2013(2): 17-20. (in Chinese)

[37] Xian Zhang, Fubin Liu, Tao Peng, Zhu Li, Bo Pang, Jian Geng. Discussion on Issues Related to Direct Transactions Between Powe Users and Power Generation Enterprises [J]. Automation of Electrical Power Systems, 2014, 38(13): 33-37. (in Chinese)

[38] Chao Shang, Jianyong Ding, Deng Xie, Dongjun Yang, Ting Hu. Method of Deviation Power Dissipation in Transmission Transaction of Inter-regional Power Grids[J]. Electric Power Construction, 2014, 35(12): 127-130. (in Chinese)

[39] Boshi Zhao, Yu Yan, Yonghui Liu, Xing Yan, Zechun Hu. Deviation Electricity Pricing Method for Cross-regional Inter-provincial Power Trading Based on Regional Power Generation Cost Approval [J]. Power System Technology, 2016,40(11):3334-3341. (in Chinese) 
[40] Zhu Li, Boshi Zhao, Xing Yan. Analysis of Deviation Electricity in Inter-regional Inter-provincial Power Trading and Deviation Power Processing Method Based on Virtual Time-Sharing Electricity Price [J]. Electric Power Construction, 2016, 37(07): 40-46. (in Chinese)

[41] Chang Zhang, Jianhua Yang, Hang Shuai, Kang'an Shu, Xiaomeng Ai. Research on Market-assisted Service based on Cross-regional Power Trading in Central China Power Grid [J]. Electric Power,2017,50(11):139-145+151. (in Chinese)

[42] Yongqi Liu, Hongpeng Zhang, Qun Li, Zhenyu Wang, Zeyu Li, Peng Zou, Qixin Chen. Design and Practice of Power Peaking Auxiliary Service Market in Northeast Power Grid [J]. Automation of Electrical Power Systems, 2017,41(10):148-154. (in Chinese)

[43] Peng Wang, Zhihui Han. The Progressive Model of Power Auxiliary Service Construction - Twenty Years of Historical Experience of China's Power Auxiliary Service Marketization [J]. China Power Enterprise Management, 2018(28): 12-15. (in Chinese)

[44] Miao He, Jun Wang. Development Experience of Foreign Power Futures Market and Its Enlightenment to China [J]. Price: Theory and Practice, 2017(12): 78-81. (in Chinese)

[45] Ming Zhou, Yu Yan, Qi Ding, Zhaoyuan Wu, Yiheng He, Suyan Long. Transaction and Settlement Mechanism of Typical Foreign Electricity Market and its Enlightenment to China [J]. Automation of Electrical Power Systems,2017,41(20):1-8+ 150. (in Chinese)

[46] Zhifei Liang, Wei Chen, Zhixiang Zhang, Junce Ding. Discussion on the Construction Mode and Path of Electric Power Spot Market in Southern China [J]. Automation of Electrical Power Systems, 2017, 41(24): 16-21+66. (in Chinese)

[47] Xian Zhang, Yaxian Zheng, Jian Geng, Longda Huang, Suyan Long, Yonghui Liu. Design of Direct Trading Platform for Power Users and Power Generation Enterprises Supporting Full-service Operation [J]. Automation of Electrical Power Systems, 2016, 40(03): 122- 128. (in Chinese)

[48] Lianjun Shi, Ping Shao, Xian Zhang, Longda Huang, Jian Yan, Fei Ye. Discussion on the Architecture of New Generation Power Market Trading Platform [J]. Automation of Electrical Power Systems, 2017, 41(24): 67-76. (in Chinese)

[49] Yanbo Chen, Sizhen Xiao. Suggestions on the Implementation of China's Power Generation Quota and Green Card Trading System [J]. China Economic \& Trade Herald, 2016(23): 8-10. (in Chinese)

[50] Dingyi Liu, Yinya Zhang, Ze Ye, Wei He. Analysis of the Principle of Coordination between Power Trading and Green Card Trading [J]. China Power Enterprise Management, 2017(28): 42-45. (in Chinese)

[51] Qi Wei, Zhaowei Zhang, Lele Wang. Experimental Research on Carbon Trading and Corporate Strategy in Power Industry [J]. Soft Science, 2015, 29(11): 115-118. (in Chinese)

[52] Guangjun Yang, Zhen Xu, Fanhui Shen. Analysis and Prospect of Carbon Emission Reduction and Participation in Carbon Trading Market in Power Generation Industry [J]. Environmental Protection, 2018, 46(15). (in Chinese) 